Skirgaile Žaltauskaitè Žalimiené

Katedra Prawa Publicznego

Uniwersytet Wileński

\title{
ZASADA BEZPIECZEŃSTWA PRAWNEGO W ORZECZNICTWIE SĄDU KONSTYTUCYJNEGO REPUBLIKI LITEWSKIEJ
}

W Postanowieniu z 14 marca 2006 r. Sąd Konstytucyjny zaznaczył, że konstytucyjna zasada państwa prawnego zobowiązuje instytucje stosujące przepisy prawa do przestrzegania ogólnych zasad prawa zatwierdzonych w orzecznictwie demokratycznych państw prawnych. Analiza orzecznictwa konstytucyjnego pozwala na wysunięcie twierdzenia, że konstytucyjną z a sadą państwa prawnego - uniwersalną zasadą, na której się opiera cały system prawny Litwy i sama Konstytucja, jest to, że konstytucyjna zasada państwa prawnego jest interpretowana nieodłącznie od deklarowanego w Konstytucji dążenia do otwartego, sprawiedliwego, spójnego społeczeństwa obywatelskiego i państwa prawnego, że treść wspomnianej powyżej zasady ukazuje się w różnych przepisach Konstytucji. Istotą tej zasady jest obowiązywanie prawa. Konstytucyjna zasada państwa prawnego jest wyjątkowo wieloznaczna, obejmuje ona dużo różnorodnych związanych ze sobą imperatywów. Na tej zasadzie należy się opierać zarówno w procesie tworzenia prawa, jak i w procesie jego wdrażania (Postanowienie Sądu Konstytucyjnego z dn. 3 lipca 2012 r.). Prof. E. Kūris konstytucyjną zasadę państwa prawnego zalicza do zasad koordynacyjnych ${ }^{1}$ i zaznacza, że różnorodne aspekty państwa prawnego, jako idee konstytucyjne przenikające wszystko, są wyrażone w różnorodnych przepisach Konstytucji: w przepisie, że Republika Litewska jest niezależną republiką demokratyczną (art. 1); w przepisie, że granice władzy wyznacza Konstytucja (część 2 art. 5); że

${ }^{1}$ Zdaniem prof. E. Kūrisa zasady koordynacyjne wpływają na regulacje utrwalone w samej Konstytucji, wpływają na to, jak jedne przepisy konstytucyjne mają się do innych oraz do zasad zapewnionych w Konstytucji. Jeśli któraś z regulacji prawnych jest sprzeczna z Konstytucją (z którymkolwiek jej przepisem), ,,automatycznie” zostaje naruszona któraś z zasad koordynacyjnych. 
Konstytucja jest aktem jednolitym i bezpośrednio stosowanym (część 1 art. 6); że każdy przepis sprzeczny z Konstytucją traci moc prawną (część 1 art. 7) i że obowiązują tylko przepisy, które zostały ogłoszone (część 2 art. 7); że prawa i wolności człowieka są prawami wrodzonymi (art. 18); także w założeniach zapewniających niezawisłość sędziów i niezależność sądów, gwarantujących pewne prawa człowieka - prawo do życia, godności, poszanowania życia prywatnego i inne ${ }^{2}$.

Jedną z podstawowych zasad państwa prawnego zapewnionych w Konstytucji Litwy jest zasada bezpieczeństwa prawnego. Ponieważ zasada bezpieczeństwa prawnego jest zasadą uniwersalną, charakterystyczną zarówno dla systemu prawnego Litwy, jak i Unii Europejskiej, więc w zakresie stosowania zasady bezpieczeństwa prawnego należy analizować nie tylko orzecznictwo konstytucyjne, ale i europejskie, ponieważ taka analiza pozwoli na ustalenie problematyki treści tej zasady lub problematyki jej stosowania na Litwie.

Zasada bezpieczeństwa prawnego woparciu o orzecznictwo konstytucyjne oznacza, że państwo ma obowiązek zapewnić pewność i stabilność regulacji prawnych, ochronę praw podmiotów prawa, ochronę praw nabytych, ochronę interesów prawnych oraz uzasadnionych oczekiwań (Postanowienia Sądu Konstytucyjnego z dn. 12 lipca 2001 r., 5 listopada 2002 r., 4 marca 2003 r., 17 marca 2003 r., 13 grudnia 2004 r., 24 grudnia 2008 r.). Ta zasada powinna służyć zapewnieniu zaufania osoby do państwa i stanowionego przez nie prawa (Postanowienie Sądu Konstytucyjnego z dn. 12 lipca 2001 r.). Analizując zasadę bezpieczeństwa prawnego, w tym postanowieniu Sąd Konstytucyjny zaznaczył dwa aspekty. Po pierwsze, imperatyw bezpieczeństwa prawnego zakłada, że pewne "wymogi powinny być stosowane w przypadku samych regulacji prawnych". Zasada bezpieczeństwa prawnego powinna być jasna i zwięzła, „normy prawne powinny być sformułowane dokładnie". Akty niższego rzędu nie mogą być sprzeczne z prawem stopnia wyższego oraz żaden akt prawny nie może być niezgodny z Konstytucją. Akty prawa „powinny być ogłaszane w określonym trybie” $\mathrm{i}$ „wszystkie podmioty prawa powinny mieć możliwość zapoznania się z nimi". Po drugie, ta zasada dotyczy kilku wymogów dotyczących ważności regulacji prawnych. W oparciu o tę zasadę regulacje prawne "można zmienić tylko zgodnie z ustalonym wcześniej trybem” i "nie naruszając” zasad i norm inter alia należy przestrzegać zasady lex retro non agit. Przez wprowadzenie poprawek do regulacji prawnych nie można przekreślić interesów prawnych oraz uzasadnionych oczekiwań osoby, powinna być zapewniona „ciągłość

${ }^{2}$ E. Kūris, Lietuvos Respublikos Konstitucijos principai//Lietuvos konstitucinè teisé, Lietuvos teisès universitetas, Vilnius 2001, s. 235-254. 
orzecznictwa”. Z tego postanowienia wynika wyraźna treść zasady bezpieczeństwa prawnego, na którą składają się dwa elementy: wymogi regulacji prawnych (zasada ta powinna być jasna i zwięzła, ogłoszona w należytym trybie) i wymogi dotyczące ważności regulacji prawnych (zmienić można w określonym trybie "nie naruszając zasad” i norm konstytucyjnych) oraz wymogi wobec orzecznictwa (ciągłość).

Problematyka dotycząca stosowania zasady bezpieczeństwa prawnego w sądach najczęściej dotyczy kwestii dostosowania kilku dóbr prawnych, a mianowicie tego, którą z kilku zasad prawnych należałoby stosować jako priorytetową w konkretnym przypadku.

\section{Wpływ przepisów prawa UE na zasadę bezpieczeństwa prawnego}

\subsection{Zasady ogólne o pierwszeństwie przepisów prawa UE w oparciu o akt Konstytucji}

Część 2 Aktu Konstytucji „O członkostwie Republiki Litewskiej w Unii Europejskiej" określa, że normy prawne Unii Europejskiej stanowią część składową porządku prawnego Republiki Litewskiej; w przypadku gdy to wynika z umów, na których opiera się Unia Europejska, normy prawne UE są stosowane bezpośrednio, zaś w przypadku kolizji norm prawnych mają one pierwszeństwo przed przepisami prawa Republiki Litewskiej oraz innymi aktami prawnymi. W Postanowieniu Sądu Konstytucyjnego z 14 marca 2006 roku szczegółowo została wyjaśniona zasada pierwszeństwa prawa unijnego przed prawem krajowym, która jest zawarta w Konstytucji. W Konstytucji została określona zasada, że w przypadkach, gdy akt prawa krajowego określa regulacje prawne kolidujące $\mathrm{z}$ regulacjami zawartymi $\mathrm{w}$ umowach międzynarodowych, stosowana jest umowa międzynarodowa, także w stosunku do przepisów prawa unijnego - expressis verbis została przyjęta zasada kolizji, utrwalająca pierwszeństwo stosowania unijnych aktów prawa w tych przypadkach, gdy przepisy unijne wynikające $\mathrm{z}$ umów, w oparciu o które funkcjonuje Unia Europejska, kolidują z regulacjami prawnymi zawartymi w krajowych aktach prawnych (niezależnie od ich mocy prawnej), z wyjątkiem Konstytucji. Profesor E. Kūris twierdzi, że we wspomnianym powyżej Postanowieniu Sądu Konstytucyjnego został „skonstruowany algorytm” współistnienia prawa konstytucyjnego Litwy i prawa Unii Europejskiej, który z jednej strony uznaje realia polityczne dotyczące dążeń do głębszej integracji i nie zapobiega należytym procesom prawnym, z drugiej zaś strony nie zaprzecza pierwszeństwu Kon- 
stytucji i hierarchii wszystkich aktów pranych z niej wynikających ${ }^{3}$. Profesor E. Jarašiūnas uważa, że zasada pierwszeństwa Konstytucji nie została naruszona. Litwa bierze udział w procesach integracji europejskiej tylko w oparciu o przepisy Konstytucji, która była pierwotną ustawą zasadniczą w kraju. Poza tym prof. E. Jarašiūnas twierdzi, że ponieważ zarówno Konstytucja, jak i prawo unijne opierają się na wspólnych wartościach, to istnieją wszelkie przesłanki do dostosowania prawa krajowego do europejskiego. Tylko harmonijne stosowanie przepisów prawa krajowego opartych na Konstytucji i przepisów prawa unijnego może zapewnić skuteczną integrację państw Europy4. Prof. E. Kūris podkreśla wagę „obopólnej przyjaznej interpretacji” stosunku prawa unijnego do Konstytucji przez konwergencję obu systemów prawnych ${ }^{5}$. Można wywnioskować, że wspomniana powyżej praktyka Sądu Konstytucyjnego oparta na normach konstytucyjnych oraz przedstawione w opracowaniach stanowisko naukowców dotyczące stosunku prawa unijnego do Konstytucji w istocie nie odpowiada koncepcji nadrzędności prawa unijnego stosowanej w praktyce przez Trybunał Sprawiedliwości Unii Europejskiej (TSUE). Z drugiej strony warto zauważyć, że ani TSUE w swojej praktyce, ani inne instytucje UE w swoich czynnościach nie dążą do zaostrzania problematyki stosunku prawa unijnego do prawa krajowego państw członkowskich. Zapewne TSUE odpowiada zasada przyjaznej interpretacji dwustronnej, która również jest akceptowana przez sądy państw członkowskich UE. Sądy, które wybierają zasadę przyjaznej interpretacji dwustronnej, powinny w każdym konkretnym przypadku poszukiwać równowagi między zasadami prawnymi, które są wspólne dla europejskiej tradycji prawnej. Ważne jest to, że zasadę nadrzędności zapewnia nie TSUE, a sądy krajowe, które są odpowiedzialne za przestrzeganie przepisów prawa unijnego w każdym państwie członkowskim.

\subsection{Zasada bezpieczeństwa prawnego w praktyce TSUE}

Ogólna zasada unijna - zasada bezpieczeństwa prawnego - wymaga, by akty prawa unijnego zezwalały osobom zainteresowanym na uzyskanie dokładnej wiedzy dotyczącej ich praw i obowiązków oraz na podejmowa-

${ }^{3}$ E. Kūris, Europos S'jungos teise Lietuvos Respublikos Konstitucinio teismo jurisprudencijoje: sambūvio algoritmo paieškos, [w:] S. Katuoka (ats. red.), Teisè besikeičiančioje Europoje. Liber Amicorum Pranas Kūris, Mykolo Romerio universiteto Leidybos centras, Vilnius 2008, s. 682-683.

${ }^{4}$ E. Jarašiūnas Kelios mintys apie Lietuvos dalyvavimo tarptautiniuose santykiuose konstituciniai pagrindai, zob. przyp. 3, s. 613-644.

${ }^{5}$ Zob. tamże przyp. 3, s. 694. 
nie odpowiednich działań (wyrok TSUE, Nijemeisland, C-170/08, 44 s.). Tworzona w oparciu o przyjętą praktykę TSUE zasada łączenia bezpieczeństwa prawnego prawa unijnego i autonomii instytucjonalnej państw członkowskich UE (gdy zasada bezpieczeństwa prawnego jest zapewniana przez stosowanie zasady równoważności i skuteczności) oraz przepis dotyczący dostosowania zasady bezpieczeństwa prawnego i nadrzędności prawa unijnego, zdaniem autorki, mogą stanowić podstawę dla Sądu Konstytucyjnego do rozwoju doktryny zasady bezpieczeństwa prawnego.

Dość często TSUE decyduje o tym, czy państwo członkowskie UE nie naruszyło zasady bezpieczeństwa prawnego. Zazwyczaj w celu wykrycia naruszeń zasady bezpieczeństwa TSUE stosuje test na równoważność i skuteczność.

TSUE w sprawie F. G. Barth (C542/08) orzekł, że okres 3 lat przedawnienia w przypadku roszczeń o wypłacenie specjalnego dodatku z tytułu stażu pracy nie jest sprzeczny z zasadą skuteczności, a tym samym i zasadą bezpieczeństwa prawnego. W danym przypadku stosując trzyletni okres przedawnienia, w oparciu o przepisy prawa krajowego niezgodne z przepisami prawa unijnego, zrezygnowano z wypłacenia dodatku specjalnego pracownikowi, który skorzystał z prawa swobodnego przepływu. Miało to miejsce przed wydaniem orzeczenia przez TSUE w dniu 30 września 2003 r. w sprawie Köbler (C224/01), chociaż wpływ Köbler na powyżej wspomnianą decyzję był spowodowany wejściem w życie interpretowanej normy, ponieważ termin ważności decyzji TSUE nie był ograniczony. Z powyższego można wywnioskować, że państwo członkowskie nie ma zakazu wyznaczenia okresu przedawnienia, po upływie którego nie można składać roszczenia o wypłacenie dodatku specjalnego za wysługę lat, który wbrew przepisom prawa UE nie był wypłacony, nawet gdyby to państwo członkowskie nie zmieniło norm prawnych tak, by były one zgodne z przepisami prawa UE. Inaczej byłoby tylko w przypadku, gdyby po zastosowaniu okresu przedawnienia, po upływie którego nie można by było złożyć wniosku o wypłacenie dodatku specjalnego za wysługę lat, człowieka całkowicie pozbawiono możliwości obrony swoich praw przed sądami krajowymi. W przypadku stosowania takiego okresu przedawnienia powód w postępowaniu przed sądem nie stracił całkowitego prawa do otrzymania dodatku specjalnego ${ }^{6}$.

Z orzecznictwa TSUE jasno wynika, że orzeczenie sądu krajowego, nawet jeśli jest ostateczne (jak to zostało potwierdzone w sprawie Komisja przeciwko Hiszpanii, C129/00), nie może być nadrzędne wobec instrumentu, przepisu lub aktu unijnego, podobnie jak przepis prawa krajowego nie może być nadrzędny w poszczególnych przypadkach wobec odpowiednich przepisów prawa unijnego lub unijnych norm konstytucyjnych.

${ }^{6}$ Gdy po uwzględnieniu orzeczenia w sprawie Köbler ustawodawca austriacki zmienił odpowiednie przepisy prawa, powód w postępowaniu przed sądem krajowym wystąpił w dn. 2 marca 2004 r. z wnioskiem do administracji Uniwersytetu Wiedeńskiego o dostosowanie jego dodatku specjalnego za wysługę lat poprzez zaliczenie okresu pracy, jaki przepracował na Uniwersytecie we Frankfurcie. Na mocy podjętej decyzji dodatek specjalny został ustalony od dnia 1 października 2000 r., chociaż również wyjaśniono, że powód w postępowaniu przed sądem krajowym mógł żądać wypłacenia dodatku specjalnego za wysługę lat już od dn. 1 stycznia 1994 r. 
Jednocześnie TSUE podkreśla wagę zasady res judicata dla systemu prawnego Unii Europejskiej oraz dla krajowych systemów prawnych. Mowa jest o kilku sytuacjach: po pierwsze, gdy się wyjaśnia, że orzeczenie sądu wyższej instancji lub orzeczenie sądu, którego zasadność została potwierdzona przez sąd ostatniej instancji, lub orzeczenie, które stało się ostatecznym, ponieważ nie było zaskarżone, jest sprzeczne z unijnymi przepisami prawa; po drugie, gdy się wyjaśnia, że podjęto decyzję o zastosowaniu przepisów prawa, którego zasadność została potwierdzona przez sąd ostatniej instancji lub upłynął termin ustalony w krajowych przepisach prawa umożliwiający zaskarżenie orzeczenia, jest sprzeczne z unijnymi przepisami prawa.

W celu poprawienia przepisów państwa członkowskie powinny zastosować wszystkie procedury wewnętrzne określone w krajowych przepisach dotyczące przeglądu ostatecznych decyzji administracyjnych (wyrok Kühne \& Heitz, C-453/00). TSUE, jeśli to możliwe, jest bardziej skłonny ocenić orzeczenie ostateczne jako akt nieuzasadniony, z powodu którego może wyniknąć odpowiedzialność państwa, niż naruszyć zasadę res judicata. Z orzecznictwa TSUE widać, że zasada bezpieczeństwa prawnego, która w istocie zapewnia stabilność prawną, w wielu przypadkach jest uważana za ważniejszą niż nadrzędność przepisów prawa UE. Orzecznictwo TSUE jest ważne, ponieważ ukazuje poziom bezpieczeństwa prawnego w Europie na poziomie prawa Unii Europejskiej oraz prawa państw członkowskich UE oraz aspekty bezpieczeństwa prawnego i aspekty dotyczące stosunku pierwszeństwa prawa unijnego. Analogicznie można zadać pytanie, czy w poszczególnych przypadkach konieczność przestrzegania zasady bezpieczeństwa prawnego nie mogłaby uzasadnić wyjątków dotyczących zasady pierwszeństwa Konstytucji Republiki Litewskiej? Stosowanie tych wyjątków byłoby aktualne na przykład, gdy decyzje administracyjne, które zostały uznane na podstawie decyzji sądowych za wiążące, były oparte na normach prawnych, które następnie zostały uznane za niezgodne z Konstytucją Litwy. Można uważać, że bezwzględne przestrzeganie zasady pierwszeństwa Konstytucji w poszczególnych przypadkach przeszkadzałoby w należytej interpretacji zasady bezpieczeństwa prawnego. Gdyby na przykład wynikła kolizja praw zatwierdzonych w Konstytucji i w Karcie Podstawowych Praw Unii Europejskiej, której założenia mają moc prawa pierwotnego UE, gdy akt administracyjny odpowiadający standardom określonym w Karcie Podstawowych Praw Unii Europejskiej gwarantuje osobie pewne prawa nie został zmieniony na mocy wiążącej decyzji sądu lub po prostu nie był zakwestionowany, wywołał pewne skutki prawne, wówczas sam akt lub jego założenia należy uznać za niezgodne z Konstytucją Litwy.

Z innej zaś strony, jurysprudencja TSUE pozwala na stwierdzenie, że sądy konstytucyjne, uzgadniając zasadę bezpieczeństwa prawnego z innymi ważnymi dobrami prawnymi, są ewidentnie ograniczane przez przepisy ustalone przez TSUE. W orzeczeniu z dn. 21 czerwca 2011 r. Sąd Konstytucyjny powtórzył sformułowanie stosowane w swojej praktyce, że orzecznictwo TSUE, jako źródło wykładni prawa, jest ważne dla wykładni i stosowania litewskiego prawa.

W orzeczeniu w sprawie Filipiak (C314/08) TSUE postanowił, że ta okoliczność, iż Trybunał Konstytucyjny „przeniósł datę, od której sporne przepi- 
sy tracą moc prawną dlatego, że są sprzeczne z założeniami Konstytucji", nie stoi na przeszkodzie, by sąd krajowy państwa członkowskiego, przestrzegając zasady zwierzchności prawa unijnego, nie stosował takich przepisów w rozpatrywanej sprawie, jeśli uważa, że te przepisy są sprzeczne z prawem unijnym. Oznacza to, że wskazówki Sądu Konstytucyjnego odnośnie do obowiązywania konkretnego przepisu prawnego i jego stosowania w poszczególnych przypadkach nie stoją na przeszkodzie, by treść takiego przepisu ocenić niezależnie od wspomnianych powyżej wskazówek i nie stosować jej, gdy zajdzie taka potrzeba. W tym przypadku oczywiste jest, że TSUE kierował się nie zasadą bezpieczeństwa prawnego, lecz zasadą nadrzędności prawa unijnego, którego stosowanie w konkretnym przypadku rodzi wątpliwość o obowiązywaniu orzecznictwa konstytucyjnego dla sądów krajowych.

W orzeczeniu w sprawie Aziz Melki (C188/10 i C189/10) TSUE rozpatrywał, czy artykuł 267 Traktatu o Funkcjonowaniu Unii Europejskiej (TFUE) zakazuje takich przepisów prawnych, które nakazują sądom „przede wszystkim postanowienie przekazania Radzie Konstytucyjnej kwestii dotyczącej konstytucyjności", która została im przedstawiona, jeśli kwestia niezgodności aktu krajowego z Konstytucją wynika ze sprzeczności tego aktu z przepisami prawa unijnego. TSUE postanowił, że art. 267 TFUE zakazuje w państwach członkowskich stosowania przepisów krajowych, które wprowadzają procedurę kontroli ad hoc nad konstytucyjnością przepisów krajowych, jeśli z powodu nadrzędności tej procedury w tej sprawie sądy krajowe nie mogłyby skorzystać z prawa lub wykonać obowiązek przedstawienia TSUE kwestii prejudycjalnych. I odwrotnie, art. 267 TFUE nie zakazuje takich przepisów prawa krajowego, jeśli sądy krajowe zachowują wolność: w dowolnej odpowiedniej (ich zdaniem) chwili do rozpatrywania sprawy, nawet po zakończeniu procedury kontroli konstytucyjnej ad hoc, przedstawienia Trybunałowi Sprawiedliwości UE dowolnej kwestii prejudycjalnej (ich zdaniem); podejmowania jakichkolwiek niezbędnych środków w celu tymczasowej ochrony praw należnych osobom w unijnym systemie prawnym i po zakończeniu tej procedury ad hoc niestosowania spornych przepisów prawa krajowego, jeśli orzekają one ich sprzeczność z przepisami unijnymi.

W orzeczeniu $A$ przeciwko $B(\mathrm{C} 112 / 13)$ TSUE ustalił, że przepisy prawa unijnego zakazują stosowania normy krajowej, w oparciu o którą sądy rozpatrujące sprawy w ostatniej instancji lub sądy apelacyjne, gdy uważają, że przepisy prawa krajowego są sprzeczne z art. 47 Karty, powinny w trakcie postępowania „skierować do Sądu Konstytucyjnego wniosek o wspólne unieważnienie przepisu, a nie tylko nie stosować tego przepisu w konkretnym przypadku", jeśli pierwszeństwo tego procesu przeszkadza tym sądom w realizacji własnego prawa lub wykonaniu własnego obowiązku i zwróceniu się do TSUE w kwestiach prejudycjalnych zarówno przed wniesieniem 
wniosku do sądu krajowego, który jest zobowiązany do dokonania kontroli konstytucyjności przepisów, jak i w przypadku wydania przez ten sąd orzeczenia w sprawie złożonego wniosku.

Pojęcie zasady bezpieczeństwa prawnego i zastosowanie tej zasady w orzecznictwie Sądu Konstytucyjnego Litwy ograniczają w orzecznictwie TSUE sformułowane zasady, których sedno stanowi zharmonizowanie dóbr konstytucyjnych i dóbr prawnych UE.

\section{Tendencje w orzecznictwie Sądu Konstytucyjnego Litwy}

W Postanowieniu z dn. 25 listopada 2002 r. Sąd Konstytucyjny orzekł, że regulacje prawne, w wyniku których wprowadzono ograniczenia możliwości wolnego wyboru pracy lub prowadzenia działalności gospodarczej wobec osoby, której została przyznana i jest wypłacana emerytura, chociaż spełnia ona warunki określone $\mathrm{w}$ przepisach prawa, by podejmować odpowiednie prace lub prowadzić działalność gospodarczą, są sprzeczne z zasadą uzasadnionych oczekiwań, pewności prawa i bezpieczeństwa prawnego oraz została naruszona zasada państwa konstytucyjnego. Jest to jedno z niewielu postanowień, w których Sąd Konstytucyjny decydował o zgodności przepisów prawa właśnie z zasadą bezpieczeństwa prawnego.

Sąd Konstytucyjny w postanowieniu z 29 listopada 2007 r., w którym rozpatrywał wsteczne wprowadzenie podatku dochodowego dla podmiotów prawnych, odrzucił działanie aktów prawa wstecz i stwierdził, że konstytucyjna zasada państwa prawnego jest związana z zasadą lex retro non agit, zgodnie z którą działanie przepisów prawa jest skierowane "na przyszłość” i przepisy prawa nie mogą działać wstecz, chyba że sytuacja podmiotów prawa uległaby polepszeniu jednocześnie bez wyrządzenia szkody innym podmiotom prawnym (lex benignor retro agit).

Sąd Konstytucyjny przestrzega zasady, że ani przepisy prawa, ani akty prawa wtórnego nie mogą ustanowić takiej regulacji prawnej, na mocy której dokona się zakłócenia już istniejących stosunków prawnych. Taka regulacja zakłócająca już istniejące stosunki prawne stworzyłaby przesłanki do odrzucenia uzasadnionych oczekiwań, pewności prawnej i bezpieczeństwa prawnego, konstytucyjnej zasady sprawiedliwości. Podobne poglądy dotyczące powyżej wspomnianej kwestii bezpieczeństwa prawnego, że przepisy prawa nie mogą działać wstecz, podzielają chyba też instytucje prawne Unii Europejskiej. Zgodnie z utrwaloną praktyką TSUE zasada bezpieczeństwa prawnego zakazuje ustalenia początku działania aktu prawa unijnego 
przed dniem jego uchwalenia, z wyjątkiem sytuacji, gdy wymaga tego interes wspólny, gdy należycie są uwzględnione uzasadnione oczekiwania osób zainteresowanych i gdy z odpowiednich dokumentów (przepisów prawnych), celów lub struktury norm prawnych wyraźnie wynika, że mają one takie oddziaływanie (Postanowienie ISD w sprawie Polska i inni przeciwko Komisji, C369/09 P, s. 98).

Zasada bezpieczeństwa prawnego była aktualna również podczas rozważania cz. 1 art. 107, na mocy której działanie zgodności aktów prawa z Konstytucją jest skierowane „na przyszłość”. W Postanowieniu z 25 października 2011 r. Sąd Konstytucyjny stwierdził, że w części 1 art. 67 (w której określono, że jest powód do stwierdzenia, że przepis prawa lub inny akt prawny, który należy stosować w konkretnej sprawie, jest sprzeczny z Konstytucją, sąd (sędzia) zawiesił postępowanie w sprawie i uwzględniając kompetencje Sądu Konstytucyjnego skierował wniosek o rozstrzygnięcie, czy dany przepis prawny lub inny akt prawny jest zgodny z Konstytucją), został zatwierdzony jeden z wyjątków dotyczący skierowania działania mocy obowiązującej postanowień Sądu Konstytucyjnego „na przyszłość”. Sąd Konstytucyjny orzekł, że chociaż z ogólnych przepisów mówiących o tym, że moc wiążąca postanowień Sądu Konstytucyjnego jest skierowana „na przyszłość”, ustawodawca nie ma obowiązku wprowadzenia regulacji prawnej, w oparciu o którą moc wiążąca postanowień Sądu Konstytucyjnego dotyczących zgodności aktów prawnych z Konstytucją byłaby skierowana retroaktywnie, a nie „na przyszłość”, jednak ta zasada „nie neguje prawa Sejmu do wprowadzenia nowej regulacji prawnej, w oparciu o którą zostałyby usunięte negatywne skutki prawne wynikające ze stosowania aktu prawnego (jego części), który został uznany przez Sąd Konstytucyjny za sprzeczny z Konstytucją". Taka regulacja prawna powinna przestrzegać zasad Konstytucji, nie może naruszać interesu publicznego, powinna spełniać inter alia wymogi konstytucyjnej zasady państwa prawnego: nie może stworzyć przesłanek do zanegowania pewności prawnej, bezpieczeństwa prawnego, powinna chronić uczciwie nabyte prawa innych osób.

Jeśli chodzi o stosowanie zasady bezpieczeństwa prawnego, istnieje wyjątkowe Postanowienie Sądu Konstytucyjnego, w którym to Sąd Konstytucyjny nie odrzuca możliwości obrony praw osób wynikających z przepisów prawnych, które następnie byłyby uznane za sprzeczne z Konstytucją. Sąd Konstytucyjny opiera się na imperatywie zachowania równowagi wartości konstytucyjnych, na wymogach dotyczących pewności prawa i bezpieczeństwa prawnego zatwierdzonego w Konstytucji, na zasadzie ochrony praw słusznie nabytych oraz domniemaniu legalności, co zdaniem Sądu Konstytucyjnego powoduje inter alia, że Konstytucja nie zapobiega w poszczególnych wyjątkowych przypadkach „zachowaniu i ochronie rów- 
nież takich praw słusznie nabytych, wynikających z aktów prawnych, które później zostały uznane za sprzeczne z Konstytucją", w wyniku odrzucenia których osoba ta, inne osoby, społeczeństwo lub państwo doznałyby większej szkody, niż gdyby wspomniane powyżej prawa zostały całkowicie lub częściowo zachowane i obronione. Z drugiej zaś strony Sąd Konstytucyjny podkreśla, że podczas podejmowania decyzji, czy prawa osoby słusznie nabyte na mocy aktu prawnego w okresie jego ważności, który później został uznany za sprzeczny z Konstytucją, powinny być zachowane i obronione lub nie, zaś jeśli tak, to $\mathrm{w}$ jakim stopniu. W każdym przypadku należy wyjaśnić, czy przez odrzucenie i niezachowanie tych słusznie nabytych praw nie zostaną naruszone inne wartości chronione konstytucyjnie, czy nie zostanie naruszona równowaga wartości, które są zatwierdzone w Konstytucji i przez nią chronione.

Stanowisko Sądu Konstytucyjnego odnośnie do możliwości obrony praw osobowych wynikających z aktów prawnych, które później zostały uznane za sprzeczne z Konstytucją, jest podobne do stanowiska TSUE odnośnie do usunięcia skutków zaskarżonego aktu prawa względem czasu (chodzi o skutki, gdy TSUE uznaje za uzasadnione roszczenie o słuszności i uznaje akt prawny za nieważny). Zarówno w oparciu o orzecznictwo Sądu Konstytucyjnego, jak i orzecznictwo instytucji Unii Europejskiej, mogą być bronione prawa osób oparte na przepisach sprzecznych z przepisami Konstytucji lub uznanych w aktach prawnych Unii Europejskiej za nieważne. To podobieństwo stanowisk może wywołać wiele pytań, ponieważ przepisy prawa litewskiego i Traktat o funkcjonowaniu Unii Europejskiej pewne kwestie regulują odmiennie. Stanowisko TSUE odnośnie do usunięcia skutków zaskarżonego aktu prawnego jest oparte na paragrafie 2 art. 264 TFUE, zgodnie z którym TSUE, jeśli uważa za niezbędne, uznając akt prawny za nieważny, może wskazać, które skutki aktu prawnego są zachowane, lecz tylko wówczas, gdy istnieją istotne motywy bezpieczeństwa prawnego, a które uzasadniają uprawnienia sądu unijnego, które po uwzględnieniu okoliczności zostały mu nadane na podstawie paragrafu 2 art. 264 TFUE (pkt. 40 Postanowienia w sprawie Parlament przeciwko Radzie (C271/94), pkt. 41 Postanowienia w sprawie Zjednoczone Królestwo przeciwko Komisji (C106/96), i pkt. 41 i 42 Postanowienia w sprawie Parlament przeciwko Radzie (C22/96)). Tymczasem zgodnie z cz. 1 artykułu 107 działanie postanowień Sądu Konstytucyjnego odnośnie do zgodności aktów prawa z Konstytucją jest skierowane „na przyszłość”, z innej zaś strony cz. 1 artykułu 110 głosi, że sędzia nie może stosować przepisów prawa, które są sprzeczne z Konstytucją.

W postanowieniu z 5 września 2012 r. Sąd Konstytucyjny podkreślił, że Sąd Konstytucyjny powinien zapewnić „ciągłość orzecznictwa” (zgodność, niesprzeczność) i przewidywalność swoich decyzji w oparciu o ukształtowaną oficjalną doktrynę konstytucyjną oraz precedensy (Postanowienia Sądu 
Konstytucyjnego z dn. 28 marca 2006 r., 21 listopada 2006 r., 22 października 2007 r., 24 października 2007 r.), przez to potwierdzając wagę elementu bezpieczeństwa prawnego - ciągłości orzecznictwa oraz jego stosowania w konkretnych przypadkach.

W postanowieniu z 12 lipca 2001 r. Sąd Konstytucyjny podkreślił jeszcze jeden aspekt w zapewnieniu bezpieczeństwa prawnego. Sąd Konstytucyjny w tym postanowieniu wskazał, że powszechnie uznaje się, iż celem zasady bezpieczeństwa prawnego jest „zapewnienie osobie zaufania do swojego państwa i systemu prawa”, lecz nie mniej istotne jest to, by „sędziowie, którzy sprawują wymiar sprawiedliwości, mieli zaufanie do swojego państwa i systemu prawa". Sędzia, podobnie jak każda osoba, ma prawo do obrony swoich praw, słusznych interesów oraz uzasadnionych oczekiwań.

$\mathrm{Na}$ podstawie analizy orzecznictwa konstytucyjnego można wysnuć wniosek, że zasada bezpieczeństwa prawnego wraz z innymi wartościami stanowi wartość konstytucyjną. Zasada bezpieczeństwa prawnego jest stosowana z innymi wartościami konstytucyjnymi w celu wyjaśnienia, która wartość konstytucyjna jest ważniejsza w konkretnych okolicznościach. Z definicji używanej przez Sąd Konstytucyjny wynika, że zasada ta dotyczy również praw podmiotów stosunków prawnych, ochrony praw słusznie nabytych, poszanowania słusznych interesów oraz uzasadnionych oczekiwań. Jednak w orzecznictwie konstytucyjnym zasada ochrony uzasadnionych oczekiwań jest wspomniana jako osobna zasada i stanowi jeden z elementów państwa prawnego. Sąd Konstytucyjny w swoim orzecznictwie najczęściej opiera się na zasadzie państwa prawnego, którego jednym z filarów jest zasada bezpieczeństwa prawnego i w niezbędnych przypadkach stwierdza sprzeczność regulacji prawnych z konstytucyjną zasadą państwa prawnego. W przypadkach, gdy Sąd Konstytucyjny opiera się na zasadzie bezpieczeństwa prawnego, wyraźnie ją wymienia w postanowieniu, zazwyczaj również jednocześnie opiera się na innych zasadach - najczęściej na zasadzie pewności prawa i uzasadnionych oczekiwań. Z tego powodu trudne jest ustalenie, jaką treść zasady bezpieczeństwa prawnego ma na uwadze Sąd Konstytucyjny w konkretnych okolicznościach. Szczególnie trudno odpowiedzieć na pytanie, czy i jak się zmienia (jeśli się zmienia) treść zasady bezpieczeństwa prawnego w orzecznictwie konstytucyjnym, zwłaszcza przy uwzględnieniu algorytmów pierwszeństwa prawa unijnego i harmonizacji wartości konstytucyjnych. Niewątpliwie w orzecznictwie Sądu Konstytucyjnego Litwy (dotyczy to zwłaszcza praw osób wynikających z aktów prawa, które zostały uznane za niezgodne z Konstytucją oraz przypadków naruszenia praw, gdy naruszenie to wynika z aktów prawnych, które następnie zostały uznane za sprzeczne z Konstytucją) uwzględniony został europejski standard zasady bezpieczeństwa prawnego uznany przez prawo unijne oraz aspekty dotyczące pierwszeństwa prawa unijnego. 